\title{
Reproduction of a fish assemblage in the state of São Paulo, southeastern Brazil
}

\author{
Gomiero, LM.* and Braga, FMS. \\ Departamento de Zoologia, Instituto de Biociências, Universidade Estadual Paulista - UNESP, \\ CP 199, Av. 24-A, 1515, CEP 13506-900 Rio Claro, SP, Brazil \\ *e-mail: leanmg@rc.unesp.br \\ Received February 11, 2005 - Accepted October 11, 2005 - Distributed May 31, 2007
}

(With 1 figure)

\begin{abstract}
Fish reproductions were studied in two river basins (Corumbataí and Jacaré-Pepira basins) in the State of São Paulo, southeastern Brazil. In the Corumbataí basin, four sites were sampled: Cabeça River, Lapa Stream, Passa-Cinco River, and Corumbataí River; in the Jacaré-Pepira basin, three sites were sampled: Tamanduá Stream, Jacaré-Pepira River, and Água Branca Stream. A total of 12 bimonthly samples were made. Fish equipment included gill nets, purse seines, sieves, and traps. The main objective of this study was to characterize the fish assemblage regarding their reproductive biology and to compare these reproductive traits between both river basins. Most individuals with gonads in stage $\mathrm{C}$ (mature) and in stage D (empty gonads) were captured in the spring and summer. Multiple spawn and parental care were common strategies, which guaranteed offspring survivorship in unstable conditions.
\end{abstract}

Keywords: reproduction, fishes, APA of São Pedro and Analândia.

\section{Reprodução de uma assembléia de peixes no estado de São Paulo, sudeste do Brasil}

\section{Resumo}

A Área de Proteção Ambiental (APA) das Cuestas de São Pedro e Analândia foi enfocada para os estudos da reprodução de peixes de duas bacias (sub-bacia do Corumbataí e bacia do Jacaré-Pepira). Na sub-bacia do Corumbataí, quatro locais de coletas foram selecionados: rio Cabeça, córrego da Lapa, rio Passa-Cinco e rio Corumbataí; enquanto que, na bacia do Jacaré-Pepira, três locais foram selecionados: córrego Tamanduá, rio Jacaré-Pepira e córrego da Água Branca. Foram realizadas 12 coletas bimestrais. Os aparelhos de pesca utilizados consistiram de redes de espera simples, tarrafa, peneiras e armadilhas do tipo covo. O objetivo deste estudo foi o de caracterizar e comparar a reprodução da assembléia de peixes das duas bacias. As coletas realizadas na primavera e no verão apresentaram o maior número de indivíduos que estavam com estádio de maturação gonadal C (maduros) e D (desovados). A desova parcelada e o cuidado parental foram estratégias comuns, que garantiram a sobrevivência da prole em condições instáveis de recursos alimentares e fatores abióticos.

Palavras-chave: reprodução, peixes, APA de São Pedro e Analândia.

\section{Introduction}

It is suggested that in tropical waters, sazonality is mainly caused by environmental factors, such as discharge of nutrients carried by rain, affecting fishes through the trophic web. However, other factors such as turbulence may exert a direct influence on the species and biotic pressures, such as competition for reproductive sites and space which may also impose sazonality in habitats relatively stable where fish community is highly diverse (Lowe-McConnell, 1999). In these habitats, alterations in the level of rivers determine variations in such availability; the rapid increase in the amount of nutrients at the beginning of the flooding season is followed by an explosion of productivity and consequently by an increase in food availability (Vazzoler and Menezes,
1992). Variable and ephemeral environmental conditions, such as those found in streams, tend to favor opportunistic species, characterized by the small size, short life span, high growth rate, early sexual maturation, and long reproductive period. Furthermore, such species are able to occupy or colonize habitats from where original fish populations were eliminated or reduced by fluctuations in abiotic conditions (Castro, 1999; Brown, 2000). In these restricted habitats, migrations are short and some special adaptations are needed for reproduction to occur (Lowe-McConnell, 1999).

According to Vazzoler (1996), the majority of the Neotropical species show a cyclic reproductive period, with gonadal development beginning before the repro- 
ductive period and completing development when environmental conditions are adequate. The extrinsic factors that indicate this period are called proximate factors or triggers. Among them are the predictors, which include photoperiod and temperature, the synchronizers, which indicate the occurrence of favorable conditions to spawn and exert influence in the final gametic maturation and individual behavior, leading to fertilization. The reproductive period ends and the gonads regress.

Sexual dimorphism is most frequent among the Characiformes and Siluriformes, where females are larger than males. This is probably related to the reproductive strategies, as fecundity increases with the size of individuals (Agostinho and Julio Jr., 1999).

The study site, although included in a governmental protected area, is surrounded by sugar cane cultivation, which is also present in the interior of the protected area. As well as this, sand ports, mineral extraction, and burns are common. Moreover, the region is highly urbanized and ecological tourism activities are developed nearby. Anthropic activities in the protected area have been causing serious impacts in the region.

The main objective of this study was to characterize the fish community of two basins (Jacaré-Pepira and Corumbataí basins) included in this protected area regarding their reproductive biology and to compare these reproductive traits between both river basins.

\section{Material and Methods}

The studied region is located in a protected area in the "cuestas" of São Pedro and Analândia. The protected area (APA) is between the latitudes $22^{\circ}$ and $23^{\circ} \mathrm{S}$ and the longitudes $47^{\circ} 30^{\prime}$ and $48^{\circ} 30^{\prime} \mathrm{W}$. Part of the area is on the Depressão Periférica and the other on the basaltic "cuestas", both in the interior of the State of São Paulo, southeastern Brazil. Climate is predominantly tropical of altitude (CWa), which is characterized by having mean annual temperatures between 18 and $22{ }^{\circ} \mathrm{C}$, with warm and wet summers and dry winters. Rainfall varies from 1,400 to $1,100 \mathrm{~mm}$. The studied area, with approximately $2,700 \mathrm{~km}^{2}$, comprises part of the municipalities of Itirapina, Brotas, São Pedro, Dois Córregos, Santa Maria da Serra, Torrinha, São Carlos, Analândia, Ipeúna, Mineiros do Tietê, Rio Claro, Barra Bonita, Corumbataí, and Itaqueri da Serra.

A total number of 12 samples were made bimonthly from 2000 to 2001, from February, April, June, August, October and December. Each sample period lasted five days.

In the Corumbataí Basin, we collected at four sample sites: the Cabeça River (point 1) - 22 22' 49" S and $47^{\circ} 39^{\prime} 55^{\prime}$ ' W, $601 \mathrm{~m}$ of altitude; the Lapa Stream (point 2) $-22^{\circ} 23^{\prime} 38^{\prime \prime} \mathrm{S}$ and $47^{\circ} 47^{\prime} 16^{\prime \prime} \mathrm{W}, 633 \mathrm{~m}$ of altitude; Passa-Cinco River (point 3) - 22 $2^{\circ} 25^{\prime} 02^{\prime \prime} \mathrm{S}$ and $47^{\circ} 42^{\prime} 47^{\prime \prime} \mathrm{W}, 567 \mathrm{~m}$ of altitude; and the Corumbataí River (point 4) - 22 08' $12^{\circ}$ ' $\mathrm{S}$ and $47^{\circ} 39^{\prime} 37^{\prime}, \mathrm{W}$, $615 \mathrm{~m}$ of altitude. In the Jacaré-Pepira Basin, we collected at three sample sites: Tamanduá Stream (point 5) - $22^{\circ} 21^{\prime} 17^{\prime \prime} \mathrm{S}$ and $47^{\circ} 45^{\prime} 00^{\prime \prime} \mathrm{W}, 642 \mathrm{~m}$ of altitude; Jacaré-Pepira River (point 6) - 22 17 ' 53" S and $48^{\circ} 11^{\prime} 35^{\prime}$ ' W, $490 \mathrm{~m}$ of altitude; and Água Branca

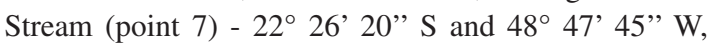
$841 \mathrm{~m}$ of altitude.

At each sample point, individuals were collected in many points along the river courses, using gill nets with mesh sizes of $1.5 ; 2.0 ; 2.5$, and $3.0 \mathrm{~cm}$, measured between adjacent knots, $5 \mathrm{~m}$ long and $1.5 \mathrm{~m}$ high. Each set of nets totalized $30 \mathrm{~m}^{2}$. Whenever possible, purse seine with mesh sizes of $1.5 \mathrm{~cm}$ and $1.5 \mathrm{~m}$ high, sieves, and traps were also used.

The sample effort was standardized keeping time and quantity of fish instruments used at each point constant. The gill nets stayed submerged from the end of the day up to the next morning. Afterwards, specimens were kept in plastic containers containing $10 \%$ formalin. Each container received a label describing the date and sample site.

Fish were identified in the laboratory up to the lowest taxonomic level. The total and standard length of individuals were measured in centimeters, mass was measured in grams, and the sex and gonadal stages were determined (Braga, 1990). The gonadal stage was determined using a stereomicroscope, or when possible, macroscopically, considering the following traits: color, transparency, surface blood vessels, and oocytes aspect. According to a previously established scale, gonadal stages were classified into four categories: $\mathrm{A}=\mathrm{im}-$ mature, $\mathrm{B}=$ in maturation or resting, $\mathrm{C}=$ mature, and $\mathrm{D}=$ empty. Ovaries in stage $\mathrm{C}$ were removed and weighed.

Intensity of reproduction in the communities was evaluated through the reproductive intensity index (IR) (Vazzoler, 1996). This method is based on the association between the frequency of individuals with gonads in stage $\mathrm{C}$ and the percentage that the mean gonadosomatic index for these individuals $\left(\mathrm{RGS}_{\mathrm{c}}\right.$ ) represent for the maximum RGS (\% $\mathrm{RGS}_{\max }$ ), whereby an estimate can be taken concerning what intensity reproduction will occur in these habitats. With such results, it was possible to classify each populational stratum as having 1) massive spawn (MS); 2) occasional spawn (OS); 3) incipient maturation (IM); and 4) no reproductive activity (NRA).

To quantify the reproductive intensity for the dominant community, in certain periods, we propose the (IR), represented by the sum of the product between an arbitrary weight $(\mathrm{W})$ and the number of specific strata $\left(\mathrm{N}_{\mathrm{sp}}\right)$ divided by the sum of the number of these strata:

$$
\mathrm{IR}=\frac{\sum\left(\mathrm{W} \cdot \mathrm{N}_{\mathrm{sp}}\right)}{\sum \mathrm{N}_{\mathrm{sp}}}
$$

where: $\mathrm{N}_{\mathrm{sp}}=$ number of strata by category; $\mathrm{W}=4$ for the massive spawn; $\mathrm{W}=2$ for the occasional spawn; $\mathrm{W}=1$ for the incipient maturation; and $\mathrm{W}=0$ for no reproduction. 
This method, apart from characterizing the use of resources by the community during the reproduction, also makes it possible to identify strata at the same level of utilization (reproductive categories) which represents group of species using the same physical habitat, with similar diets, and close life cycles (Vazzoler, 1996).

\section{Results}

The IR method (reproductive intensity index) was applied for populations of both river basins. The first step was to determine the frequency of individuals at each different maturity stage. Some species were chosen as they were collected at different sample sites. These species were: Hypostomus strigaticeps, Astyanax altiparanae, Astyanax scabripinnis, Characidium aff. zebra, Piabina argentea, Hypostomus ancistroides, Parodon tortuosos, Astyanax fasciatus, Hypostomus sp1., Phalloceros caudimaculatus, Astyanax sp1., Serrapinus heterodon, and Bryconamericus sp.

The species Astyanax fasciatus and Phalloceros caudimaculatus, from basin 1 (Corumbataí Basin), and Characidium aff. zebra, Hypostomus ancistroides, Parodon tortuosus, and Serrapinus heterodon, from basin 2 (Jacaré-Pepira Basin), were not sampled enough. Individuals of Hypostomus sp1., from basin 1, and those of Astyanax scabripinnis, Piabina argentea, and Bryconamericus sp., from basin 2, did not show the gonadal stage $\mathrm{C}$ and were also excluded from the analysis (Table 1).

In both basins, the species reproductive categories were determined associating the frequency of individu-

Table 1. Frequency of the maturity stages (A: immature; B: maturation or resting; C: mature; and D: empty) of the most captured species in both basins in all samples (N: number of collected individuals).

\begin{tabular}{|c|c|c|c|c|c|}
\hline \multicolumn{6}{|c|}{ Basin 1 (Corumbataí) } \\
\hline \multirow[t]{2}{*}{ Species } & \multirow[b]{2}{*}{$\mathbf{N}$} & \multicolumn{4}{|c|}{ Maturity stage (\%) } \\
\hline & & $\mathbf{A}$ & B & C & D \\
\hline Hypostomus strigaticeps & 267 & 5.23 & 82.35 & 7.19 & 5.23 \\
\hline Astyanax altiparanae & 233 & - & 65.44 & 8.82 & 25.74 \\
\hline Astyanax scabripinnis & 542 & 0.87 & 76.42 & $16.59^{\mathrm{a}}$ & 6.11 \\
\hline Characidium aff. zebra & 74 & - & 65.00 & $32.50^{\mathrm{a}}$ & 2.50 \\
\hline Piabina argentea & 334 & - & 82.84 & $13.24^{\mathrm{a}}$ & 3.92 \\
\hline Hypostomus ancistroides & 143 & 2.38 & 76.19 & $16.67^{\mathrm{a}}$ & 4.76 \\
\hline Parodon tortuosus & 75 & - & 35.56 & $42.22^{\mathrm{a}}$ & 22.22 \\
\hline Astyanax fasciatus & 16 & - & 22.22 & $55.56^{\mathrm{b}}$ & 22.22 \\
\hline Hypostomus sp1. & 28 & 8.33 & 91.67 & - & - \\
\hline Phalloceros caudimaculatus & 4 & - & - & $100.00^{\mathrm{b}}$ & - \\
\hline Astyanax sp1. & 189 & - & 79.00 & $18.00^{\mathrm{a}}$ & 3.00 \\
\hline Serrapinus heterodon & 44 & - & 36.36 & $59.09^{\mathrm{a}}$ & 4.55 \\
\hline Bryconamericus sp. & 120 & 1.30 & 74.03 & $18.18^{\mathrm{a}}$ & 6.49 \\
\hline \multicolumn{6}{|c|}{ Basin 2 (Jacaré-Pepira) } \\
\hline \multirow[t]{2}{*}{ Species } & & \multicolumn{4}{|c|}{ Maturity stage (\%) } \\
\hline & $\mathbf{N}$ & $\mathbf{A}$ & B & $\mathrm{C}$ & D \\
\hline Hypostomus strigaticeps & 51 & 3.57 & 89.29 & 3.57 & 3.57 \\
\hline Astyanax altiparanae & 66 & - & 48.94 & $25.53^{\mathrm{a}}$ & 25.53 \\
\hline Astyanax scabripinnis & 3 & - & 100.00 & - & - \\
\hline Characidium aff. zebra & 6 & - & - & $100.00^{\mathrm{b}}$ & - \\
\hline Piabina argentea & - & - & - & - & - \\
\hline Hypostomus ancistroides & 2 & - & 50.00 & $50.00^{\mathrm{b}}$ & - \\
\hline Parodon tortuosus & 3 & - & 50.00 & $50.00^{\mathrm{b}}$ & - \\
\hline Astyanax fasciatus & 99 & 1.56 & 67.19 & $25.00^{\mathrm{a}}$ & 6.25 \\
\hline Hypostomus sp1. & 21 & - & 76.92 & $15.38^{\mathrm{a}}$ & 7.69 \\
\hline Phalloceros caudimaculatus & 531 & 0.23 & 42.89 & $56.88^{\mathrm{a}}$ & - \\
\hline Astyanax sp1. & 820 & 1.86 & 58.51 & $25.70^{\mathrm{a}}$ & 13.93 \\
\hline Serrapinus heterodon & 4 & - & 66.67 & $33.33^{\mathrm{b}}$ & - \\
\hline Bryconamericus sp. & - & - & - & - & - \\
\hline
\end{tabular}

${ }^{a}$ Frequency of individuals with mature ovaries, which isolated, suggests that the species could reproduce in the area; and

${ }^{\mathrm{b}}$ Insufficient number of individuals. 
als with the gonadal stage $\mathrm{C}$ with the percentage that the mean gonadosomatic relationship (RGS) represented in the maximum RGS (\% RGS max $_{\text {max }}$ for the six periods (Table 2). However, some species were excluded from the analysis due to the low values of these parameters.

For each species, reproductive categories were presented by the period and basin, as well as the values of each category. The category MS occurred in more species in October, 2000 and 2001 in both basins. The IR was calculated by the period in both basins (Table 3 ). In basin 1, the higher values of IR were 2.62 and 2.25, referring to samples made in October and December, respectively. In basin 2, the highest value of IR was 3, referring to samples made in October.

Figure 1 shows the values of IR in both basins during the six periods, and for both basins, it is clear that the IR increased in the spring (October) and in the summer (December and February).

From data on the total length and gonadal stage, we estimated the $\mathrm{L}_{50}$, and so we obtained the percentage of juveniles $\left(\mathrm{L}_{\mathrm{t}}<\mathrm{L}_{50}\right)$ and adults $\left(\mathrm{L}_{\mathrm{t}}>\mathrm{L}_{50}\right)$ of these species (Table 4). For some species it was not possible to obtain the $\mathrm{L}_{50}$ due to the low number of individuals with gonadal stage A.

In basin 1 (Corumbataí), juveniles were more abundant for the species Astyanax scabripinnis and Hypostomus ancistroides, and in basin 2 (Jacaré-Pepira), for the species Astyanax sp1. However, adults predominated in all species sampled. These data were compared with those presented by Vazzoler (1996) and we observed that, due to the mean IR in both basins, the points sampled were used as reproductive and foraging sites by the studied species.

\section{Discussion}

In general, spawn peaks of sympatric and closely related species, or species using the same resources, do not coincide (Lowe-McConnell, 1999). When and where spawns occur represent adaptations to protect eggs and juveniles from enemies and to provide them with food sources (Nikolskii, 1969). In teleosts, ovulation is regulated both by endogenous and by exogenous factors, and is often a quick answer to specific factors, such as temperature variations, pheromones, or substratum for reproduction (Stacey, 1984).

In the tropics, rain and water level are the main agents inducing reproduction (Rizzo et al., 1996). Availability of food affects reproduction, oocyte production and fecundity (Nikolskii, 1969).

Most of the species analyzed here had mature gonads in the spring and summer, eight were mature throughout the year, only one species was mature in the fall and winter, and 10 species did not present mature gonads at the sample sites during the studied period.

The presence of individuals with gonads macroscopically mature in a restrict area of its occurrence is not concrete evidence that spawn will occur at this site (Vazzoler, 1996). However, the occurrence of gonads in stage D (empty) may indicate recent spawn in the species.

In the Upper Paraná Basin, the period of reproduction starts in October, when the temperature is high and water levels begin to rise, reaching its peak in DecemberJanuary (Vazzoler and Menezes, 1992). In the Barra Funda Stream (SP), the main breeding period of fish occurs in the warm and rainy season (spring and summer), with $74 \%$ of species growing and reproducing at this same site (Garutti, 1988).

The prolonged breeding period of some species may result from the occurrence of multiple spawns, which could avoid competition among juveniles (Nikolskii, 1963), leading them to make better use of the resources at the same time.

Individuals from many species of lambaris (Astyanax altiparanae, Astyanax scabripinnis, and Astyanax fasciatus) had mature gonads throughout the period of samples. However, in other places, this occurred mainly in the spring and summer: the period of floods (Nomura, 1975; Barbieri et al., 1982; Agostinho et al., 1984; Rodrigues et al., 1989; Barbieri, 1992a; Barbieri, 1992b; Santos et al., 1995; Alkins-Koo, 2000). Individuals of Astyanax sp1. were in stages $\mathrm{C}$ and D, mainly in the fall and winter, and the same was observed for lambaris reared in captivity (MG) and in the Tabajara Stream (SP) (Andrade et al., 1985; Uieda, 1984; respectively). Headwater populations of Astyanax altiparanae show a more prolonged reproductive period, with many peaks, whereas populations in the rivers tend to have a relatively shorter reproductive period (Garutti, 1989). The distinct reproductive patterns shown by the species are adaptations to temporal and spatial variations in environmental parameters, food availability, and predation pressure (Winemiller, 1989), and are rather an ecological adaptation than a genetic phenomenon (Lopes et al., 2000).

The cascudos, Hypostomus strigaticeps and Hypostomus ancistroides had a prolonged reproductive period, contrasting to what was registered by Barbieri and Verani (1987) and Barbieri and Santos (1987). Prolonged breeding may be due to the low fecundity and parental care, as in Mazzoni and Caramaschi (1995).

The canivetes, Apareiodon piracicabae and A. ibitiensis had mature gonads in the spring and summer. However, mature gonads were present throughout the period in Parodon tortuosus, with a peak also occurring in the spring and summer. These species show multiple spawns (Barbieri et al., 1985) and this fact can lead to an increase in the breeding period. According to Sazima (1980), A. piracicabae reproduced in the rainy season (spring and summer), with individuals congregating at shallow areas, next to rocks, in order to spawn. Barbieri et al. (1983) registered that the reproductive period occurred from July to October for A. ibitiensis, and from October to December for P. tortuosus. In the Passa-Cinco River, P. tortuosus showed only one ovary and the reproductive peak was from September 


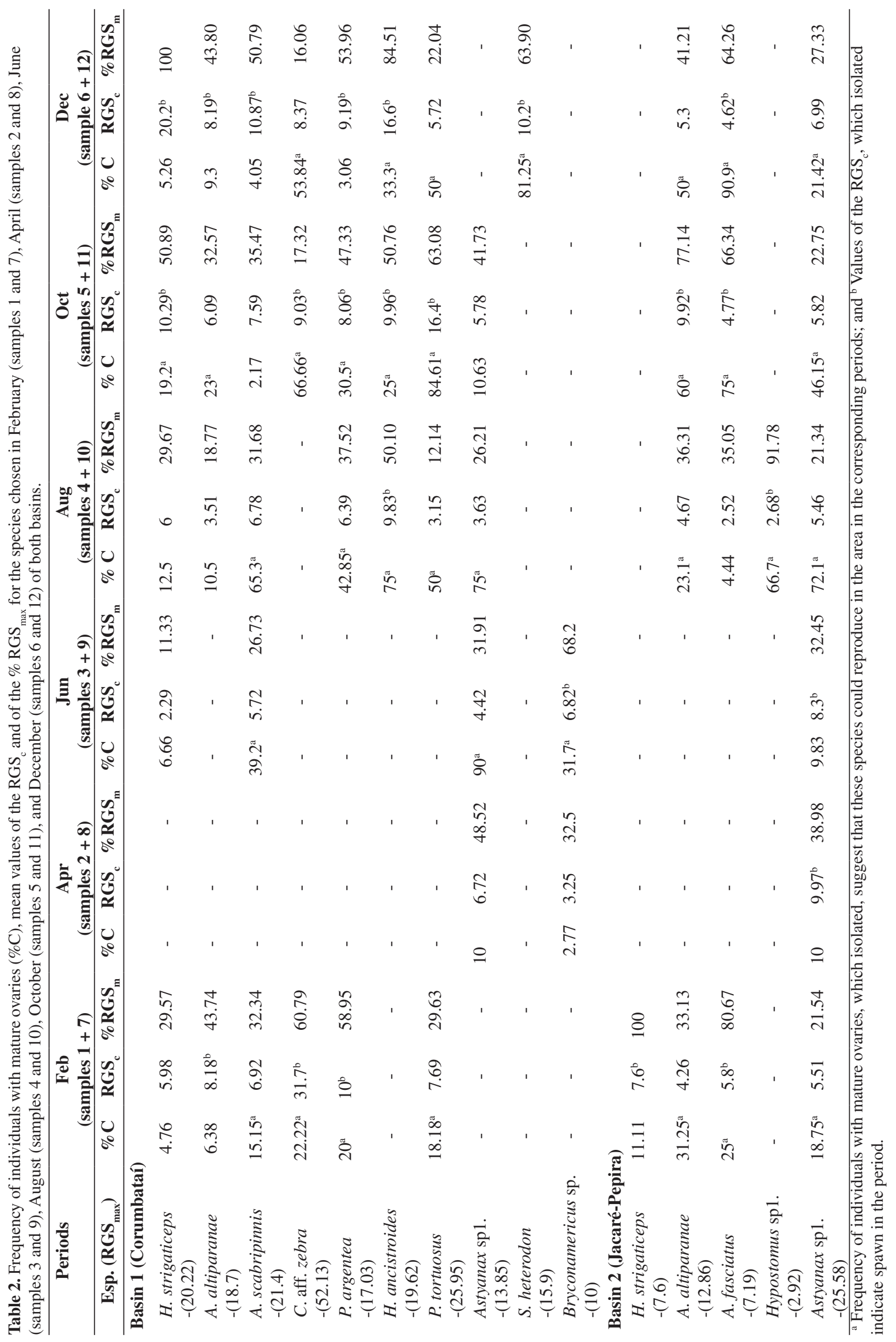



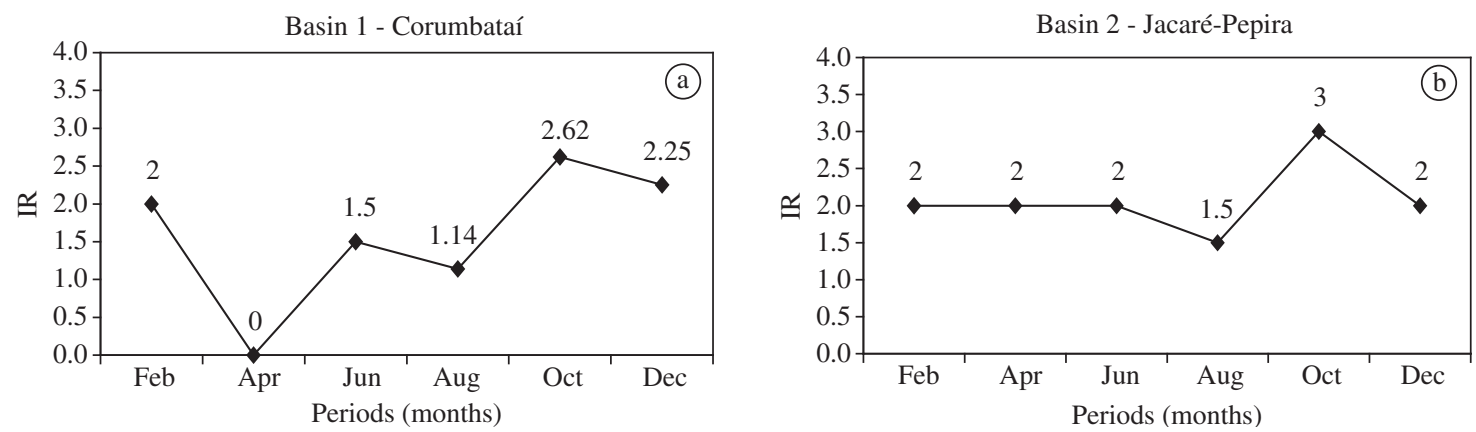

Figure 1. Graphic representation of the temporal variation in the reproductive intensity of the chosen species in each basin.

Table 3. Reproductive categories (MS: massive spawn; OS: occasional spawn, IM; incipient maturation, NRA; no reproductive activity) of the chosen species and the reproductive intensity (IR), by basin, in February (samples 1 and 7); April (samples 2 and 8); June (samples 3 and 9); August (samples 4 and 10); October (samples 5 and 11); and December (samples 6 and 12).

\begin{tabular}{|c|c|c|c|c|c|c|}
\hline Specie/period & February & April & June & August & October & December \\
\hline \multicolumn{7}{|l|}{ Basin 1 (Corumbataí) } \\
\hline H. strigaticeps & NRA & - & NRA & NRA & MS & OS \\
\hline A. altiparanae & OS & - & - & NRA & $\mathrm{IM}$ & OS \\
\hline A. scabripinnis & $\mathrm{IM}$ & - & IM & $\mathrm{IM}$ & NRA & OS \\
\hline C. aff. zebra & MS & - & - & - & MS & $\mathrm{IM}$ \\
\hline P. argentea & MS & - & - & $\mathrm{IM}$ & MS & OS \\
\hline H. ancistroides & - & - & - & MS & MS & MS \\
\hline P. tortuosus & $\mathrm{IM}$ & - & - & IM & MS & $\mathrm{IM}$ \\
\hline Astyanax sp1. & - & NRA & IM & IM & NRA & - \\
\hline S. heterodon & - & - & - & - & - & MS \\
\hline Bryconamericus sp. & - & NRA & MS & - & - & - \\
\hline MS & $4 \times 2=8$ & $4 \times 0=0$ & $4 \times 1=4$ & $4 \times 1=4$ & $4 \times 5=20$ & $4 \times 2=8$ \\
\hline OS & $2 \times 1=2$ & $2 \times 0=0$ & $2 \times 0=0$ & $2 \times 0=0$ & $2 \times 0=0$ & $2 \times 4=8$ \\
\hline $\mathrm{IM}$ & $1 \times 2=2$ & $1 \times 0=0$ & $1 \times 2=2$ & $1 \times 4=4$ & $1 \times 1=1$ & $1 \times 2=2$ \\
\hline NRA & $0 \times 1=0$ & $0 \times 2=0$ & $0 \times 1=0$ & $0 \times 2=0$ & $0 \times 2=0$ & $0 \times 0=0$ \\
\hline IR & 2 & 0 & 1.5 & 1.14 & 2.62 & 2.25 \\
\hline \multicolumn{7}{|l|}{ Basin 2 (Jacaré-Pepira) } \\
\hline H. strigaticeps & OS & - & - & - & - & - \\
\hline A. altiparanae & $\mathrm{IM}$ & - & - & $\mathrm{IM}$ & MS & $\mathrm{IM}$ \\
\hline A. fasciatus & MS & - & - & NRA & MS & MS \\
\hline Hypostomus sp1. & - & - & - & MS & - & - \\
\hline Astyanax sp1. & IM & OS & OS & $\mathrm{IM}$ & IM & IM \\
\hline MS & $4 \times 1=4$ & $4 \times 0=0$ & $4 \times 0=0$ & $4 \times 1=4$ & $4 \times 2=8$ & $4 \times 1=4$ \\
\hline OS & $2 \times 1=2$ & $2 \times 1=2$ & $2 \times 1=2$ & $2 \times 0=0$ & $2 \times 0=0$ & $2 \times 0=0$ \\
\hline $\mathrm{IM}$ & $1 \times 2=2$ & $1 \times 0=0$ & $1 \times 0=0$ & $1 \times 2=2$ & $1 \times 1=1$ & $1 \times 2=2$ \\
\hline NRA & $0 \times 0=0$ & $0 \times 0=0$ & $0 \times 0=0$ & $0 \times 1=0$ & $0 \times 0=0$ & $0 \times 0=0$ \\
\hline IR & 2 & 2 & 2 & 1.5 & 3 & 2 \\
\hline
\end{tabular}

to November (Azevedo et al., 1988a; Azevedo et al., 1988b; Barbieri and Cruz-Barbieri, 1989).

Individuals of Loricaria piracicabae did not have mature gonads and individuals of Rineloricaria latirostris and Rineloricaria sp. had mature gonads in the spring and summer. These genera exhibit parental care and sexual dimorphism (Moodie and Power, 1982) with low fecundity (Armbruster, 1998), and reproduction may occur before the rainy period (Lowe-McConnell, 1999).

The piau, Leporinus friderici, had mature gonads in the spring and summer, as registered by Lopes et al. (2000). 
Table 4. Mean length at first gonadal maturation $\left(\mathrm{L}_{50}\right)$, frequency of juvenile and adult phases $(\% \mathrm{~J}, \% \mathrm{~A})$, number of collected individuals $(\mathrm{N})$, and number of adults (NA) for the chosen species of both basins.

\begin{tabular}{|c|c|c|c|c|c|}
\hline \multirow[t]{2}{*}{ Species } & \multirow[t]{2}{*}{$\mathrm{L}_{50}(\mathrm{~cm})$} & \multicolumn{2}{|c|}{ Phase (\%) } & \multicolumn{2}{|c|}{ Structure } \\
\hline & & $\mathbf{J}$ & A & $\mathbf{N}$ & NA \\
\hline \multicolumn{6}{|l|}{ Basin 1 (Corumbataí) } \\
\hline H. strigaticeps & a & 2.6 & $97.4^{\mathrm{b}}$ & 267 & 260 \\
\hline A. altiparanae & 6.2 & 3.44 & $96.56^{\mathrm{b}}$ & 233 & 225 \\
\hline A. scabripinnis & 4.2 & 19.2 & $80.8^{\mathrm{b}}$ & 542 & 438 \\
\hline C. aff. zebra & a & 0 & $100^{\mathrm{b}}$ & 74 & 74 \\
\hline P. argentea & 3.75 & 4.5 & $95.5^{\mathrm{b}}$ & 334 & 319 \\
\hline H. ancistroides & 9.2 & 19.6 & $80.4^{\mathrm{b}}$ & 143 & 115 \\
\hline P. tortuosus & a & 2.67 & $97.33^{\mathrm{b}}$ & 75 & 73 \\
\hline Astyanax sp1. & a & 4.23 & $95.77^{\mathrm{b}}$ & 189 & 181 \\
\hline S. heterodon & a & 0 & $100^{\mathrm{b}}$ & 44 & 44 \\
\hline Bryconamericus sp. & 4.1 & 7.5 & $92.5^{\mathrm{b}}$ & 120 & 111 \\
\hline \multicolumn{6}{|l|}{ Basin 2 (Jacaré-Pepira) } \\
\hline H. strigaticeps & a & 1.96 & $98.04^{\mathrm{b}}$ & 51 & 50 \\
\hline A. altiparanae & a & 0 & $100^{b}$ & 66 & 66 \\
\hline A. fasciatus & a & 4.05 & $95.95^{\mathrm{b}}$ & 99 & 95 \\
\hline Hypostomus sp1. & a & 9.52 & $90.48^{\mathrm{b}}$ & 21 & 19 \\
\hline Astyanax sp1. & 3.6 & 30.13 & 69.87 & 820 & 573 \\
\hline
\end{tabular}

* It was not possible to determine the $\mathrm{L}_{50}$ due to the low number of individuals in stage $\mathrm{A}$; and ${ }^{\mathrm{b}}$ Predominance of adults, that isolated, may suggest a reproductive area of the species.

For Corydoras, C. aeneus did not show mature gonads and $C$. flaveolus had mature gonads in the spring and summer. In the Alambari River (SP), reproduction of C. aeneus occurred in the summer (Aranha et al., 1993), the same occurring in Trinidad (Alkins-Koo, 2000). Sexual dimorphism, multiple clutch, and mature females throughout the year with more intensity in the summer can be observed for headwater callichthyids (Araújo and Garutti, 2002).

Individuals of Characidium aff. zebra had mature gonads in the spring and summer (rainy season), as observed by Uieda (1984).

Individuals of Hoplias malabaricus had mature gonads in the spring and summer. At site 7 (Água Branca Stream), small size individuals were present, suggesting that all developmental phases occur at this site. At the Monjolinho dam (São Carlos - SP), this species had multiple clutches mainly from September to October (Barbieri, 1989).

Specimens of Hoplosternum littoralis did not have mature gonads at the sample sites. In Venezuela, this species has a significant sexual dimorphism and reproduces during the floods (Winemiller, 1987), constructing floating nests amidst aquatic macrophytes in order to protect the eggs and juveniles (Machado-Allison, 1990). This behavior could explain the scarcity of mature individuals in our samples.
The acará, Geophagus brasiliensis had mature gonads in the spring and summer. This species shows parental care, sexual dimorphism, multiple clutch, and low fecundity (Barbieri et al., 1978).

Specimens of Corumbataia cuestae did not have mature gonads at the sample sites. However, this species has large oocytes and low fecundity (Britski, 1997).

Individuals of Bryconamericus sp. were mature during the spring and summer. In the Andean streams, $B$. deuterodonoides reproduced in the dry season at very shallow sites (Flecker et al., 1991).

The guarus, Poecilia reticulata and Phalloceros caudimaculatus, reproduced throughout the studied period. In Trinidad, Poecilia reproduced throughout the year experiencing intense fluctuations (Alkins-Koo, 2000). In these small fish, fertilization is internal, sexual dimorphism is significant (Bisazza and Pilastro, 1997), and they are often at disturbed sites (Uieda and Barreto, 1999). In the Cedro Stream (SP), a disturbed stream in the interior of the São Paulo state, $P$. reticulata were predominant at deep sites; the short life span and internal fertilization minimize the choice for places to spawn, making it possible to survive in such unpredictable habitats (Lemes and Garutti, 2002).

In Panamá, in the Frijolito River, abiotic conditions are very stable and the various reproductive periods are explained by the availability of food sources for juveniles and adults, interspecific competition of juveniles by 
food, controlled by competition for sites for reproduction, and reproductive isolation; or they are not related to local conditions but result from previous evolutionary events, leading to specialization to spawn under certain environmental conditions (Kramer, 1978).

In the Venezuelan "llanos", Winemiller (1989) registered three reproductive strategies: 1) the equilibrium strategy, which includes fish with parental care and aseasonal reproduction, such as Hoplias malabaricus, Hoplosternum littoralis, Hypostomus, Loricaria, Rineloricaria, Geophagus brasiliensis, Corydoras flaveolus, Corydoras aeneus, Hisonotus sp., and Corumbataia cuestae; 2) the opportunistic strategy, including small fish, without parental care, and with continuous reproduction (multiple clutches), such as Bryconamericus sp., Characidium aff. zebra, Piabina argentea, Poecilia reticulata, Serrapinus cf. notomelas, Phalloceros caudimaculatus, Serrapinus heterodon, and Odontostilbe microcephalus; and 3) the seasonal strategy, including fish with seasonal and cyclical reproduction, without parental care, and showing high fecundity, such as Astyanax, Steindachnerina insculpta, Apareiodon piracicabae, Apareiodon ibitiensis, Parodon tortuosus, Rhamdia quelen, Pimelodella, Leporinus friderici, Salminus hilarii, Acestrorhynchus lacustris, Galeocharax knerii, Eigenmania cf. trilineata, Cyphocarax modestus, Leporinus obtusidens, and Schizodon nasutus. These reproductive strategies are very similar to those described for the High Paraná Basin (Agostinho and Julio Jr., 1999). These authors proposed three divisions as follows: 1) fish with external fertilization, large migrants, and without parental care; 2) fish with external fertilization, non migrants, and without parental care, and 3) fish with external fertilization, non migrants, and with parental care. However, for stream fish, the first classification of Winemiller (1989) was more suitable as it does not consider whether fertilization is internal or external.

Knowledge of reproductive tactics is fundamental to comprehend the species life cycle strategies, which are crucial to direct administration, management, and preservation measures from certain human actions, such as fishing, pollution, and elimination of reproductive areas by constructing dams and destroying marginal vegetation (Vazzoler and Menezes, 1992).

According to Vazzoler (1996), the species that presented massive spawn (MS) must complete all life cycle phases in the area. In basin 1 (Corumbataí), such species were: Hypostomus strigaticeps, Characidium aff. zebra, Piabina argentea, Hypostomus ancistroides, Parodon tortuosos, Serrapinus heterodon, and Bryconamericus sp.; in basin 2 (Jacaré-Pepira), the species were: Astyanax altiparanae, Astyanax fasciatus, and Hypostomus sp1. Most individuals from the species having occasional spawn (OS) reach gonadal maturation but abandon the area to spawn in other regions, however, some individuals spawn in the area (basin 1, the species: Hypostomus strigaticeps, Astyanax altiparanae, Astyanax scabripinnis, and Piabina argentea; basin
2, the species: Hypostomus strigaticeps and Astyanax sp1.). The species in the category of incipient maturation (IM) grow and/or forage in the area, where the maturation process begins, but abandon the region in the initial phases of maturation (basin 1, the species: Astyanax altiparanae, Astyanax scabripinnis, Characidium aff. zebra, Piabina argentea, Parodon tortuosus, and Astyanax sp1.; basin 2, the species: Astyanax altiparanae and Astyanax sp1.). The species that did not show reproductive activity (NRA) only grow and/or forage in the area (basin 1, the species: Hypostomus strigaticeps, Astyanax altiparanae, Astyanax scabripinnis, Astyanax sp1., and Bryconamericus sp.; basin 2, the species: Astyanax fasciatus). The analyses of the basin were divided by period, and because of that some species were classified in more than one category in different periods.

The Reproductive Intensity method (IR), besides characterizing the use of resources by the species during reproduction, makes it possible to identify strata in the same level of use (reproductive categories). Moreover, it quantifies the energy invested in gonadal development, when constructing models on ecosystem operation (Vazzoler, 1996). The IR increased in the spring and summer in both basins, demonstrating that most of the species reproduce in this period.

The ecological theory predicts that when first gonadal maturation occurs precociously in small size animals, there is an efficiency to increase the populational genetic representation in the future generation (Vazzoler, 1996). All mean lengths of first maturation $\left(\mathrm{L}_{50}\right)$ obtained were less than $10 \mathrm{~cm}$, indicating the length when half of the population of each species reaches maturity. These lengths are inherent to each species, but we can note a tendency of reduction in the length in this mature species.

Traits of fish equipment used and the sample sites may have contributed to the low catch of juveniles of some species, but for the species Astyanax scabripinnis, Hypostomus ancistroides, and Astyanax sp1., the portions sampled were important for the juveniles as foraging and growing sites.

Most reproductive activity of the studied species occurred in the spring and summer, periods that coincide with the increase in temperature and rainfall, providing better survival conditions for offspring. Some species showed evidence of multiple spawning and parental care, strategies that ensure the better use of resources in unstable habitats

The studied areas were used by some species as foraging and reproductive sites.

Acknowledgments - The authors acknowledge FAPESP for the graduate fellowship given to LM. Gomiero and to IBAMA for the research permits.

\section{References}

AGOSTINHO, AA. and JÚLIO JR., HF., 1999. Peixes da bacia do alto rio Paraná. In Estudos ecológicos de comunidades 
de peixes tropicais. LOWE-McCONNELL, R. H. Editora da Universidade de São Paulo, São Paulo, p. 374-400.

AGOSTINHO, CA., MOLINARI, SL., AGOSTINHO, AA. and VERANI, JR., 1984. Ciclo reprodutivo e primeira maturação sexual de fêmeas do lambari, Astyanax bimaculatus (L.) (Osteichthyes-Characidae) do rio Ivaí, Estado do Paraná. Rev. Brasil. Biol., vol. 44, no. 1, p 31-36.

ALKINS-KOO, M., 2000. Reproductive timing of fishes in a tropical intermittent stream. Env. Biol. Fish., vol. 57, no.1, p. $49-66$.

ANDRADE, DR., GODINHO, HP., RIBEIRO, SP. and CASTRO, EFT., 1985. Ciclo reprodutivo anual de lambaris (Astyanax bimaculatus Linnaeus, 1758) em viveiros. Arq. Bras. Med. Vet. Zoot., vol. 37, no. 5, p. 435-447.

ARANHA, JMR., CARAMASCHI, EP. and CARAMASCHI, U., 1993. Ocupação espacial, alimentação e época reprodutiva de duas espécies de Corydoras Lacépède (Siluroidei, Callichthyidae) coexistentes no rio Alambari (Botucatu, São Paulo). Rev. Brasil. Zool., vol. 10, no. 3, p. 453-466.

ARAUJO, RB. and GARUTTI, V., 2002. Biologia reprodutiva de Aspidoras fuscoguttatus (Siluriformes, Callichthyidae) em riacho de cabeceira da bacia do alto rio Paraná. Iheringia, Sér. Zool., Porto Alegre, vol. 92, no. 4, p. 89-98.

ARMBRUSTER, JW., 1998. Modifications of the digestive tract for holding air in Loricariid and Scoloplacid catfishes. Copeia, vol. 3, no. 3, p. 663-675.

AZEVEDO, CO., BARBIERI, MC. and BARBIERI, G., 1988a. Ciclo reprodutivo de Parodon tortuosus (Eigenmann and Norris, 1900) do rio Passa-Cinco, Ipeúna-SP. I. Estádios de maturação dos testículos. Época de reprodução. Rev. Brasil. Biol., vol. 48, no. 3, p. 565-569.

-, 1988b. Ciclo reprodutivo de Parodon tortuosus (Eigenmann and Norris, 1900) do rio Passa-Cinco, Ipeúna-SP. II. Estádios de maturação do ovário. Época de reprodução. Rev. Brasil. Biol., vol. 48 , no. 3 , p. $571-575$.

BARBIERI, G., 1989. Dinâmica da reprodução e crescimento de Hoplias malabaricus (Bloch, 1794) (Osteichthyes, Erythrinidae) da represa do Monjolinho, São Carlos/SP. Rev. Brasil. Zool., vol. 6, no. 2, p. 225-233.

-, 1992a. Dinâmica da nutrição de Astyanax scabripinnis paranae (Characiformes, Characidae) do ribeirão do Fazzari: São Carlos, SP. Rev. Soc. Bras. Zoot., vol. 21, no. $1,68-72$.

-, 1992b. Biologia de Astyanax scabripinnis paranae (Characiformes, Characidae) do ribeirão do Fazzari. São Carlos. Estado de São Paulo. II. Aspectos quantitativos da reprodução. Rev. Brasil. Biol., vol. 52, no. 4, p. 589-596.

BARBIERI, G., BARBIERI, MC. and MARINS, MA, 1978. Biologia de Geophagus brasiliensis (Quoy and Gaimard, 1824), na represa do Lobo, estado de São Paulo. III: Aspectos quantitativos da reprodução. I Seminário brasileiro de aquicultura. Acad. Brasil. Ci., Rio de Janeiro, p. 347-359.

BARBIERI, G. and CRUZ-BARBIERI, M., 1989. Growth and first sexual maturation size of Parodon tortuosus Eigenmann and Norris, 1900 from Passa Cinco river (Ipeúna, São Paulo State, Brazil) (Osteichthyes, Parodontidae). Naturalia, vol. 14, p. $45-54$.

BARBIERI, G. and SANTOS, EP., 1987. Crescimento e tamanho da primeira maturação gonadal de Hypostomus aff. plecos- tomus (Linnaeus, 1758) (Osteichthyes, Loricariidae), da represa do Monjolinho. (São Carlos, SP). Ciência e Cultura, vol. 39, no. 7, p. 659-663.

BARBIERI, G., SANTOS, MVR. and SANTOS, JM., 1982. Época de reprodução e relação peso/comprimento de duas espécies de Astyanax (Pisces, Characidae). Pesq. Agropec. Brasil., vol. 17, no. 7, p. 1057-1065.

BARBIERI, G. and VERANI, JR., 1987. O fator de condição como indicador de desova em Hypostomus aff. plecostomus (Linnaeus, 1758) (Osteichthyes, Loricariidae), na represa do Monjolinho (São Carlos, SP). Ciência e Cultura, vol. 39, no. 7 , p. 655-658.

BARBIERI, G., VERANI, JR. and BARBIERI, MC., 1983. Análise do comportamento reprodutivo das espécies Apareiodon affinis (Steindachner, 1879), Apareiodon ibitiensis Campos, 1944 e Parodon tortuosus Eigenmann and Norris, 1900 do rio Passa-Cinco, Ipeúna, S.P. (Pisces, Parodontidae). An. Sem. Reg. Ecol. III, p. 189-199.

BARBIERI, G., VERANI, JR., PEREIRA, JA., BARBIERI, MC., PERET, AC. and MARINS, MA., 1985. Curva de maturação e fator de condição de Apareiodon affinis (Steindachner, 1879), Apareiodon ibitiensis (Campos, 1944) e Parodon tortuosos (Eigenman and Norris, 1900) do rio Passa Cinco IpeúnaSP. (Cypriniformes, Parodontidae). Ciência e Cultura, vol. 37, no. 7 , p. $1178-1183$.

BISAZZA, A. and PILASTRO, A., 1997. Small male mating advantage and reversed size dimorphism in poeciliid fishes. J. Fish Biol., vol. 50, no. 2, p. 397-406.

BRAGA, FMS., 1990. Aspectos da reprodução e alimentação de peixes comuns em um trecho do rio Tocantins entre Imperatriz e Estreito, estado do Maranhão e Tocantins, Brasil. Rev. Brasil. Biol., Rio de Janeiro, vol. 50, no. 3, p. 547-558.

BRITSKI, HA., 1997. Descrição de um novo gênero de Hypoptopomatinae, com duas espécies novas (Siluriformes, Loricariidae). Pap. Avul. de Zool., vol. 40, no. 15, p. 231-255.

BROWN, LR., 2000. Fish communities and their associations with environmental variables, lower San Joaquin river drainage, California. Env. Biol. Fish., vol. 57, no. 3, p. 251-269.

CASTRO, RMC., 1999. Evolução da ictiofauna de riachos sul-americanos: padrões gerais e possíveis processos causais. In: Ecologia de peixes de riachos. Série Oecologia Brasiliensis, v. 6, PPGE-UFRJ, Rio de Janeiro, Brasil, eds. CARAMASCHI, E. P., MAZZONI, R. and PERES-NETO, P. R., p. 139-155.

FLECKER, AS., TAPHORN, DC., LOVELL, JA. and FEIFAREK, BP., 1991. Drift of characin larvae, Bryconamericus deuterodonoides, during the dry season from Andean piedmont streams. Env. Biol. Fishes, vol. 31, no. 2, p. 197-202.

GARUTTI, V., 1988. Distribuição longitudinal da ictiofauna em um córrego da região noroeste do Estado de São Paulo, bacia do rio Paraná. Rev. Brasil. Biol., vol. 48, no. 4, p. 747-759.

GARUTTI, V., 1989. Contribuição ao conhecimento reprodutivo de Astyanax bimaculatus (Ostariophysi, Characidae), em cursos de água da bacia do rio Paraná. Rev. Brasil. Biol., vol. 49, no. 2, p. 489-495.

KRAMER, DL., 1978. Reproductive seasonality in the fishes of a tropical stream. Ecology, vol. 59, no. 5, p. 976-985. 
LEMES, EM. and GARUTTI, V., 2002. Ictiofauna de poção e rápido em um córrego de cabeceira da bacia do Alto rio Paraná. Comun. Mus. Ciênc. Tecnol., vol. 15, no. 2, p. 175-199.

LOPES, CA., BENEDITO-CECILIO, E. and AGOSTINHO, A. A., 2000. The reproductive strategy of Leporinus friderici (Characiformes, Anostomidae) in the Paraná river basin: the effect of reservoirs. Rev. Brasil. Biol., vol. 60, no. 2, p. 255-266.

LOWE-McCONNELL, RH., 1999. Estudos ecológicos de comunidades de peixes tropicais. Editora da Universidade de São Paulo, São Paulo, p. 535.

MACHADO-ALLISON, A., 1990. Ecología de los peces de las areas inundables de los llanos de Venezuela. Interciencia, vol. 15 , no. 6 , p. 411-423.

MAZZONI, R. and CARAMASCHI, EP., 1995. Size structure, sex ratio and onset of sexual maturity of two species of Hypostomus. J. Fish Biol., vol. 47, no. 5, p. 841-849.

MOODIE, GEE. and POWER, M., 1982. The reproductive biology of an armoured catfish, Loricaria uracantha, from Central America. Env. Biol. Fish., vol. 7, no. 2, p. 143-148.

NIKOLSKII, GV., 1963. The ecology of fishes. Academic Press, London and New York, p. 352.

NIKOLSKII, GV., 1969. Theory of fish populations dynamics. Oliver and Boyd. Edinburgh, p. 323.

NOMURA, H., 1975. Fecundidade, maturação sexual e índice gônado-somático de lambaris do gênero Astyanax Baird and Girard, 1854 (Osteichthyes, Characidae), relacionados com fatores ambientais. Rev. Brasil. Biol., vol. 35, no. 4, p. 775-798.

RIZZO, E., SATO, Y., FERREIRA, RMA., CHIARINIGARCIA, H. and BAZZOLI, N., 1996. Reproduction of Leporinus reinhardti Lütken, 1874 (Pisces: Anostomidae) from the Três Marias reservoir, São Francisco river, Minas Gerais, Brazil. Ciência e Cultura, vol. 48, no. 3, p. 189-192.

RODRIGUES, AM., RODRIGUES, JD., CAMPOS, EC. and FERREIRA, AE., 1989. Aspectos da estrutura populacional e época de reprodução do tambiú Astyanax bimaculatus
(Characiformes, Characidae) na represa de Bariri, rio Tietê, estado de São Paulo, Brasil. Bol. Inst. de Pesca., São Paulo, vol. 16, no. 1, p. 97-110.

SANTOS, RA., GIAMAS, MTD., CAMPOS, EC., CAMARA, JJC. and VERMULM JUNIOR, H., 1995. Dinâmica da nutrição do tambiú Astyanax bimaculatus Linnaeus, 1758 (Pisces, Characiformes, Characidae) na represa de Ibitinga, Estado de São Paulo, Brasil. Bol. Inst. Pesca, vol. 22, no. 1, p. 115-124.

SAZIMA, I., 1980. Behavior of two Brazilian species of parodontid fishes, Apareiodon piracicabae and A. ibitiensis. Copeia, vol. no. 1, p. 166-169.

STACEY, NE., 1984. Control of timing of ovulation by exogenous and endogenous factors. In: Fish reproduction: strategies and tactics. Eds. POTTS, G. W. and WOOTON, R. J., LONDRES, Academic Press, cap. 12, p. 207-222.

UIEDA, VS., 1984. Ocorrência e distribuição dos peixes em um riacho de água doce. Rev. Brasil. Biol., vol. 44, no. 2, p. 203-213.

UIEDA, VS. and BARRETO, MG., 1999. Composição da ictiofauna de quatro trechos de diferentes ordens do rio capivara, bacia do Tietê, Botucatu, São Paulo. Rev. Brasil. Zooc., vol. 1, no, 1, p. $55-67$.

VAZZOLER, AEAM., 1996. Biologia da reprodução de peixes teleósteos: Teoria e Prática. Maringá-PR, Nupelia, p. 169.

VAZZOLER, AEAM. and MENEZES, NA., 1992. Síntese de conhecimento sobre o comportamento reprodutivo dos Characiformes da América do Sul (Teleostei, Ostariophysi). Rev. Brasil. Biol., vol. 52, no. 4, p. 627-640.

WINEMILLER, KO., 1987. Feeding and reproductive biology of the currito, Hoplosternum littorale, in the Venezuelan llanos with comments on the possible function of the enlarged male spines. Env. Biol. Fish., vol. 20, no. 3, p. 219-227.

WINEMILLER, KO., 1989. Patterns of variation in life history among South American fishes in seasonal environments. Oecologia, vol. 81, no. 2, p. 225-241. 